Etnográfica

Revista do Centro em Rede de Investigação em

Antropologia

vol. $24(2) \mid 2020$

Vol. 24 (2)

\title{
Mestria da pesca: cultura de um ofício
}

Mastery of fishing: the culture of an artisanal occupation

\section{Cristiano Wellington Noberto Ramalho}

\section{CpenEdition \\ Journals}

\section{Edição electrónica}

URL: https://journals.openedition.org/etnografica/7730

DOI: 10.4000/etnografica.7730

ISSN: 2182-2891

\section{Editora}

Centro em Rede de Investigação em Antropologia

\section{Edição impressa}

Data de publição: 1 junho 2020

Paginação: 315-337

ISSN: 0873-6561

Refêrencia eletrónica

Cristiano Wellington Noberto Ramalho, «Mestria da pesca: cultura de um ofício», Etnográfica [Online], vol. 24 (2) | 2020, posto online no dia 31 julho 2020, consultado o 20 janeiro 2022. URL: http:// journals.openedition.org/etnografica/7730 ; DOI: https://doi.org/10.4000/etnografica.7730

\section{(c) (i) (9)}

Etnográfica is licensed under a Creative Commons Attribution-NonCommercial 4.0 International License. 


\section{Mestria da pesca: cultura de um ofício}

\section{Cristiano Wellington Noberto Ramalho}

Partindo das próprias representações, sentimentos e práticas societárias dos pescadores artesanais da praia de Suape, no litoral sul de Pernambuco, este artigo busca analisar a relação íntima que esses trabalhadores do mar efetivam entre arte e trabalho, aspectos constitutivos e constituídos da atividade pesqueira na região, na cultura de aprendizagem de seu ofício pesqueiro, onde a pessoa do mestre de pescaria assume papel central.

PALAVRAS-CHAVE: pescador artesanal, mestres de pesca, socioantropologia da pesca.

Mastery of fishing: the culture of an artisanal occupation - The article explores the representations, feelings and partnership practices of artisanal fishermen from Suape beach, in Pernambuco's south coast, to investigate the connection they establish between work and art, both constitutive aspects of fisheries in the area, and its expression in the learning culture of their craftsmanship, where the fishing master plays a central role.

KEYWORDS: artisanal fisheries, fishing masters, socio-anthropology of fisheries.

RAMALHO, Cristiano Wellington Noberto (cristiano.ramalho@yahoo.com.br) Departamento de Sociologia (DS), Universidade Federal de Pernambuco (UFPE), Brasil. 


\section{APRESENTAÇÃO}

O presente escrito objetiva apresentar e discutir as relações entre trabalho e arte na pesca artesanal, compreendendo-as como parte da cultura de um ofício, de um saber-fazer pesqueiro em que a mestria pesqueira é a personagem essencial.

Embora a abordagem se fundamente, em alguns momentos, em elementos mais gerais no âmbito teórico, tem como base empírica os pescadores do mar alto da praia de Suape, no município do Cabo de Santo Agostinho, que se situa na região metropolitana do Grande Recife, no litoral sul de Pernambuco, no Nordeste do Brasil. ${ }^{1}$

A aproximação entre trabalho e arte na condição da cultura de um ofício artesanal encontra razão no fato de ter emergido, na aludida localidade, em falas, sentimentos e práticas societárias entre os marítimos, que categorizam o trabalho pesqueiro enquanto arte (a arte de ser pescador artesanal) e o pescador mestre como o principal artista e educador desse saber-fazer.

Os resultados apresentados e discutidos nas páginas seguintes têm origem na opção pela pesquisa etnográfica, com base na história de vida de 13 pescadores (oito mestres de pesca e cinco proeiros - explicarei esses personagens ao longo do escrito) e nas observações diretas, seja do dia a dia desses trabalhadores no continente, seja dos momentos vividos com eles em mar alto em seus barcos. O período da pesquisa de campo durou de dezembro de 2004 a dezembro de 2006.

\section{UMA BREVE ABORDAGEM HISTÓRICA}

Quando do surgimento do capitalismo mercantil na Europa, as corporações de ofício eram os territórios da existência de diversas artes e das técnicas para exercê-las em plenitude. De maneira geral, herança do período grego antigo, a ideia de arte foi difundida e vivida na época medieval europeia - em cidades italianas, francesas, inglesas, alemãs, portuguesas, espanholas - como articulação precisa de comandos técnicos efetivados no trabalho (Langhans 1948; Martins 2017; Rugiu 1998).

Até então não existia uma distinção entre trabalho e arte; aliás, ocorria uma simbiose entre ambas, visto que o artista "era tratado com um trabalhador e foi essa a sua posição durante toda a Idade Média” (Osborne 1970: 39). A arte era também entendida como algo útil e, por isso, não desvinculada de sua função social, porque nem ela e nem o artista estavam separados do seu público, em termos de comunhão e uso dos produtos artísticos e das demandas sociais em relação a estes, independentemente de ser vista como arte vil ou não, fato 
que reverberou até à expansão e hegemonia da Revolução Industrial e, assim, do modo de produção capitalista no continente europeu (Peixoto 2003; Wolff 1981).

Nesse período, a noção de arte como trabalho foi trazida ao Brasil pela colonização portuguesa, através dos mestres artesãos e das corporações que aqui aportaram e/ou foram (re)criadas na forma de confrarias e/ou de irmandades religiosas, tornando-se algo comum entre os trabalhadores vinculados a essas formas de associação na época colonial, de 1500 a 1822, e do Império, de 1822 a 1889 (Cunha 2000), o que também aconteceu no estado de Pernambuco, onde a presença dos mestres de ofícios fez-se marca indelével (Mac Cord 2012; Freyre 2003).

E foi desse modo que a ideia e o sentimento de arte foram vividos em várias localidades brasileiras: a arte como articulação precisa de comandos técnicos, apuro e destreza exercida num trabalho bem feito, uma junção entre saber e fazer, tendo como centro o processo da mestria. Nesse processo, os mestres (alfaiates, carpinteiros, sapateiros, ourives, etc.), no trabalho em suas oficinas em conjunto com seus aprendizes e demais artífices, comandavam, ensinavam e detinham o domínio de todas as etapas produtivas, que iam da organização à execução das tarefas. Quem planejava não se encontrava dissociado do espaço de execução do trabalho, inexistindo, assim, uma separação entre classes sociais, ou uma dissociação entre trabalho e capital, entre quem planejava e quem executava.

De acordo com Hobsbawm, "um ofício compreendia todos aqueles que tinham adquirido as técnicas peculiares de uma ocupação mais ou menos difícil, através de um processo específico de educação" (1987: 355). Então, o manejo da técnica era compartilhado, pois o próprio trabalho necessitava disso. Ademais, esses homens estavam no mesmo espaço em que observavam, analisavam e aprendiam o que o mestre fazia e/ou repassava em sua prática diária, no processo de mestria. Enfim, a arte era compartilhada para que pudesse ser realizada. E "ao mestre não cabia unicamente a função instrutora, mas o caráter educativo do processo de aprendizagem profissional, individual e social do aprendiz" (Martins 2008: 83).

Vale mencionar que o termo mestre é originário do latim magister, cujos significados são o que ensina, aconselha, conduz e/ou guia na elaboração de uma obra. A prática da mestria está presente desde a Idade Média, visto que "é na antiga organização dos mesteres que o termo mestre assume o seu significado. O mestre dirige a oficina, mas, ao dirigi-la, ensina e simultaneamente, cria uma obra" (Serrão 1971: 48, grifos no original). De modo geral, "as oficinas estabelecem um movimento de coesão entre as pessoas através dos rituais do trabalho" (Sennett 2009: 88), o que foi capaz de gerar "um senso de dignidade e de autoestima, derivado do trabalho manual difícil, bom e útil à sociedade" (Hobsbawm 1987: 372), fazendo com que os artífices portassem 
a "[...] crença justificada de que sua técnica era indispensável à produção; na verdade [a] crença de que ela era o único fator indispensável à produção" (Hobsbawm 1987: 358, grifo no original), elemento típico de uma cultura de ofício.

Além disso, os artífices eram chamados, de maneira geral no Brasil-colônia e no Brasil-império, de artistas, e o inverso era corriqueiro, quer fossem praticantes de ofícios (artes) liberais ou não. Luiz Antônio Cunha, apoiando-se em documento de época, escreveu:

"Alguns artistas, cujas atividades assemelhavam-se tecnicamente às dos oficiais mecânicos, diferiam deles pelas características sociais do seu trabalho dotado de valor simbólico, como os arquitetos, os escultores (às vezes chamados de entalhadores) e os pintores. Não eram chamados de mecânicos nem estavam sujeitos à agremiação corporativa, como era o caso da maioria destes. Eram os oficiais liberais, embora essa denominação não fosse comum, sendo a mais empregada a de artistas, confundindo-se, neste caso, com a categoria homônima à empregada para os oficiais mecânicos" (Cunha 2000: 28-29, grifos no original).

Ao estudar essa questão em Pernambuco, o historiador Francisco Augusto Pereira da Costa mostrou (com base numa contenda estabelecida em 13 de novembro de 1756 junto à câmara de Recife, entre mestres que eram favoráveis e os contrários à presença de negros escravos nos ofícios) como o termo artista era empregado para os profissionais, até mesmo os escravos, voltados aos ofícios mecânicos (ou artesanais), mostrando ser uso bastante corrente, no período, a classificação de artista dada a esses trabalhadores:

"Naquele ato discutiu a câmara os prejuízos que a oposição dos juízes acarretava aos senhores de escravos artistas, bem como ao público, porquanto as obras por êles produzidas eram mais baratas, e notando-se ainda, que se êles trabalhassem nas oficinas dos forros, tiravam esses para si uma têrça ou quarta parte dos seus jornais, com grave prejuízo não só dos senhores como dos consumidores" (Costa 1954: 145, grifos no original].

Outra informação expressiva é o recenseamento da população brasileira de 1872, onde aparecem dentro da categoria de artesanato as seguintes profissões: costureiras, artistas, alfaiates, carpinteiros e pescadores (Barbosa 2008). O termo artesão, que foi absorvido no Brasil, é também uma herança de Portugal; na documentação histórica portuguesa, "quando os documentos mencionam artesão, estão geralmente a referir-se a barbeiros, alfaiates, sapateiros, pedreiros, carpinteiros, oleiros, padeiros, almocreves, carniceiros, pescadores e outros semelhantes" (Marques 1985: 169). 
Também as falas dos pescadores mais velhos de Suape apontam para isso:

"Meu avô sempre me ensinou. Ele era mestre, e me falou que o pescador é um artesão, por conta da sua habilidade para trabalhar no mar" [seu Gidinha, 70 anos, mestre de Suape, PE].

"O mestre pescador é uma espécie de artista, de artesão das águas. Aprendi isso de novinho com os mais velhos" [seu Neneu, 67 anos, mestre de Suape, PE].

Como se nota, essa cultura da mestria estava presente no modo de organização do trabalho pesqueiro, inclusive em várias localidades pernambucanas com seus mestres de ofício (Silva 2001), dentre as quais Suape, o que permitiu um encontro entre arte e trabalho na pesca artesanal, na qual o papel do mestre da pesca foi e é central para a reprodução dessa cultura de ofício (Ramalho 2017).

Mas qual o motivo para que isso continuasse no trabalho pesqueiro artesanal? Diferentemente dos praticantes de outras artes, que sofreram com a expansão do capitalismo (alfaiates, carpinteiros, ferreiros, ourives, sapateiros e outros), os pescadores artesanais sentiram, responderam e vivenciaram esse processo de maneira não tão perversa, já que o desenvolvimento capitalista na pesca nunca se operou com a mesma força do que aconteceu em outros setores produtivos em Pernambuco, devido às implicações e às mediações sociais e ecológicas peculiares do mundo do trabalho marítimo.

A pesca artesanal nunca perdeu sua hegemonia em Pernambuco. Ainda hoje, ela detém mais de $98 \%$ do pescado capturado no mar, estuários e rios locais de maneira extrativista. Tal fato deve-se às próprias características naturais do ambiente, já que a plataforma costeira pernambucana é estreita e cheia de corais, tornando inadequado o uso de redes industriais na pesca, e também à inexistência de cardumes de grande porte como existentes no Sul do Brasil, os quais são de interesse prioritário para as grandes empresas pesqueiras (Ramalho 2017).

É claro que as corporações de pescadores também deixaram de existir, como aconteceu com os demais ofícios artesanais, porém a organização do trabalho inspirada, em boa medida, nas antigas artes dos artífices, na mestria inspirada nas corporações, não se extinguiu em muitas comunidades de trabalhadores do mar, ecoando em suas culturas produtivas.

A continuidade do sentimento de corporação de ofício ainda é algo muito presente na pesca artesanal. Segundo Diegues (1983: 197), tal sentimento de corporação, pelo qual "os pescadores artesanais se identificam com um grupo possuidor de uma profissão", distinguiria esses trabalhadores dos pescadores -lavradores em São Paulo, e, para Junqueira (2003: 10), faz com que se sintam, ainda hoje, "quase uma corporação, com linguagem e hábito próprios, 
os homens do mar formam um grupo à parte", já que "sua atividade produtiva afirma e respalda noções de uma cultura do trabalho, de uma ideologia produtiva, que expressa sentimentos de arte e de liberdade e que formam e conferem valor à própria existência da comunidade local" (Ramalho 2017: 116).

Mesmo em outros trabalhos esse fenômeno sobreviveu quase por um século, após a declaração do fim das corporações no Brasil em 1824 (Silva 2003). ${ }^{2}$ Mais do que a lei, foi a expansão do capital em determinados ramos econômicos que pôs fim aos mestres, à visão do trabalho como arte e a uma cultura do trabalho em bases mais igualitárias, onde o trabalho suplantava o valor do capital; em outros ramos, onde continuaram, as respostas dos trabalhadores e o avanço do capital ocorreram em outras bases, visto que os termos mestre ou artista popular (os outrora praticantes das artes manuais) ainda sobrevivem, podendo ser encontrados em artesãos estudados por Porto Alegre (1994) e nos ourives de Juazeiro do Norte, CE, pesquisados por Alvim (1972).

Especificamente no caso da pesca artesanal pernambucana, se ainda há uma cultura do trabalho de forte inspiração na sociedade do trabalho dos artífices, no processo de mestria, isso não quer dizer que ela sobreviveu incólume e nem se dá de maneira semelhante ao passado. Contudo, pode-se afirmar que, sem dúvida, o processo de socialização, o longo tempo para a feitura do mestre, a organização do trabalho no mar, a centralidade do saber-fazer do trabalho, o valor de uso mais intenso que o valor de troca, o controle dos meios de produção, a permanência de algumas técnicas e tecnologias guardam diversos aspectos vivos e fundantes do mencionado sentimento de corporação, para o qual a mestria é decisiva.

Em suma, o mundo do trabalho pesqueiro não foi capturado e interferido na mesma medida que outros setores econômicos, outras artes, devido ao modo peculiar que o desenvolvimento capitalista assumiu nas regiões costeiras de muitas localidades e às mediações societárias (políticas, culturais, ambientais) presentes no cotidiano dos trabalhadores pesqueiros. Ao não ser capturada em igual medida ou plenamente, a sociabilidade do trabalho ainda continua assumindo eixo central no fazer desses profissionais. Então, a lógica de compreender o seu trabalho como arte e como liberdade - como fazem atualmente os pescadores suapenses -, e as práticas de sociabilidade geradas pelos marítimos, têm no passado sua raiz importante e que é capaz de ainda oferecer pistas valiosas para se entender o tempo presente, o ser e o fazer-se mestre pescador.

2 No ano de 1824, é decretado, por meio da constituição política do império, o fim legal das corporações de ofício, após dois anos da independência do Brasil frente ao governo lusitano. Tal decreto foi reforçado pela lei promulgada em 1 de outubro de 1828 e "que deu nova forma às câmaras municipais, não prevendo a participação de representantes dos ofícios mecânicos, como juízes de ofício, procuradores ou, ainda, juízes do povo" (Cunha 2000: 56). 
A MESTRIA: LÓCUS PRIVILEGIADO DA ARTE DE SER PESCADOR ARTESANAL

O pescador mestre e o domínio da arte da pescaria (em seu amplo universo) são sinônimos para os embarcados da praia de Suape. Alcançar e possuir a mestria representa o ponto de chegada e de partida da arte de pescar, da própria produção e reprodução da cultura do ofício pesqueiro artesanal.

Para ser pescador artesanal não basta sobreviver da pescaria, é preciso compreender e conhecer plenamente os meios sobre os quais aquele dirige seu trabalho, bem como ser construtor de práticas societárias, de sociabilidades singulares típicas desse ofício (Diegues 1983; Lima 1997; Maldonado 1994).

O fazer da mestria resulta de um profundo saber, especialmente numa atividade que exige uma rigorosa necessidade de relacionar aspectos complexos, como ventos, marés, ciclos lunares, tipos de cardumes, armadilhas certas para capturar determinados peixes, velocidade a impor à embarcação, profundidade da área em que se busca capturar os pescados, bem como o comando e a cooperação entre homens no mar.

Nesse contexto, a pessoa do mestre é essencial na pescaria. Para Maldonado, "falar-se de mestre e da mestrança é falar de algo universal e indissociável à pesca" (1994: 134, grifos no original)", pois não existe ninguém melhor do que esse personagem para congregar a arte de ser pescador, ${ }^{3}$ sendo resultado e educador de uma cultura de ofício ensinada e aprendida secularmente, como acontece na praia de Suape (Ramalho 2017).

Só existe mestre porque há uma arte desenvolvida, aprendida e repassada. Isso ainda é muito presente na pesca artesanal de Suape, pois o mestre atua como um educador de uma arte, de um saber-fazer pesqueiro, sendo um guia do mundo aquático.

Pude observar isso quando embarquei, em inúmeras oportunidades. A ação do mestre orientava e direcionava os rumos náuticos e pesqueiros dos tripulantes, sendo uma autoridade reconhecida pelo domínio da arte pesqueira. Sem dúvida, como ressaltou seu Milton, o mestre de pescaria "se compara a um professor" [pescador mestre, 67 anos, Suape, PE]. Ele é um professor que se faz "o guia da tripulação" [Conrado, pescador mestre, 39 anos, Suape, PE], o elo com os usos ancestrais das águas e transmissor da confiança pautada no domínio da arte de ser pescador artesanal.

O mestre é uma instituição, pois armazena em si um patrimônio societário. Ele é o responsável pela prévia ideação da arte, o planejamento de todas as etapas, a organização do grupo de trabalho e o nascimento da obra. Esses elementos devem ser sempre divididos com os demais trabalhadores de sua oficina marítima (a embarcação), em prejuízo de se não obter uma boa qualidade produtiva. Seu comando se edifica pela experiência e capacidade reconhe-

3 O mestre é personagem também comum as mais diversas atividades artesanais que existem até hoje no Brasil. 
cida por todos no mundo prático do saber-fazer, e se articula a um diálogo ao mesmo tempo vertical (a partir do responsável) e horizontal (do trabalho coletivo e voluntário) com os membros da unidade de produção, cujas relações de trabalho assentam-se, na grande maioria das situações, em vínculos pessoais e diretos. Na pesca artesanal, "os laços de família e a prática da mestrança amparam, alimentam e se projetam umbilicalmente" (Ramalho 2006: 162).

Os desafios inerentes ao mar cobram que a tripulação tenha também amplo conhecimento dos fatores que envolvem seu trabalho. O mestre compreende essa importância, pois, se o domínio do saber-fazer pesqueiro não for socializado (é claro que não na plenitude do mestre, porque isso leva tempo e decorre de capacidades individuais) junto aos embarcados, o risco de morte em alto-mar será elevado.

A cooperação de saberes e de fazeres não é só necessária, é a própria razão de ser da pesca artesanal, da companha. As formas tradicionais de trabalho assentadas na lógica da companha (ou regime de parceria) são as regras da pesca artesanal, de maneira geral, em diversas localidades brasileiras, de norte a sul (Diegues 1983; Ramalho 2006), bem como na Espanha (Galván Tudela 1989) e na Itália (Collet 1993). Na realidade, companha e parceria são a mesma coisa. É uma forma de organização do trabalho que se sustenta na cooperação, na qual os laços de compadrio, de amizade e familiares têm peso decisivo. Não existe trabalho assalariado, mas uma repartição do ganho por meio do quinhão; o capital não suplanta internamente a força do trabalho, das relações sociais, afetivas, a valorização do saber-fazer.

Embora ocorra uma relação mais horizontal na pesca artesanal, isso não significa que diferenças não existam, especialmente aquelas fundadas no conhecimento sobre o mar e os locais mais piscosos (a autoridade do mestre explicita isso). Porém, esse sentimento de igualdade entre grupos de pescadores, encontrado em outras localidades no Brasil (Diegues 2000; Maldonado 1994), ganha força em Suape devido à condição de posse dos instrumentos de trabalho, especialmente dos barcos motorizados, pois, dos pescadores entrevistados, menos de $10 \%$ trabalhavam em embarcações de terceiros, isto é, a maioria (90\%) trabalha em sistema de parceria (ou companha), em barco próprio e/ou familiar.

Todos os pescadores, devido à socialização no barco, sentem-se e se autointitulam, em Suape, de artistas do mar - porque pescar, de alguma maneira, já é arte -, embora não no mesmo nível do mestre. Por exemplo, os proeiros devem ter qualidades que os credenciam para executar seu trabalho, de colocar e retirar a rede da água com precisão, pôr os covos, dialogar com o ritmo do mar no momento da "despesca", mostrando-se hábeis em seu saber-fazer. ${ }^{4}$ Sem esse requisito, a pescaria pode fracassar.

4 Proeiro é o pescador que trabalha na proa da embarcação, ficando responsável pelo ato de pesca, de colocar e retirar as redes e demais armadilhas das águas sob o comando do mestre. 
“Todo pescador tem que ser talentoso" [Alberis, proeiro, 52 anos].

"Entrou no barco, tem que ter habilidade, tem que ter a arte" [seu Gidinha, mestre, 70 anos, Suape, PE].

"No mar, a gente faz tudo. O que aparecer, o pescador tem que fazer" [Joaquim, proeiro, 25 anos, Suape, PE]. ${ }^{5}$

O saber-fazer, assim, torna-se uma condição básica para o exercício da pesca artesanal, um domínio compartilhado e chão construtor de uma identidade comum entre os pescadores, de uma mesma sociedade do trabalho. Algo similar é relatado por Duarte em relação aos pescadores do Rio de Janeiro:

"O saber fazer constituiria, de certo modo, o fundo comum à prática pesqueira que envolve todos os pescadores e que remete assim àquela identidade abrangente [...]. Ele se consubstancia no domínio das práticas mais imediatas ou técnicas do processo de trabalho, tais como o saber atar (recolher a rede traineira), o saber puxar (recolher a rede de arrasto) etc." (Duarte 1999: 93-94, grifos no original).

A força do verbo fazer não é exclusiva ao âmbito da pesca artesanal em Suape, encontrando-se presente no imaginário dos trabalhadores das usinas de açúcar de Pernambuco e no atributo de "artista", que eles conferem a poucos trabalhadores das oficinas que executam sua atividade produtiva com base na cooperação simples e, portanto, no não parcelamento das tarefas, como acontece com outros funcionários do setor. Segundo Lopes, “o fazer do artista ressalta o aspecto artesanal de seu trabalho, no sentido de ver sua obra acabada após ter percorrido ele próprio as etapas necessárias à sua realização" (1976: 36). É esse fazer amplo e concreto que diferencia o trabalhador artista de outros profissionais na usina. Para Lopes, "o código da arte, interno aos operários, não necessita de um 'teste' formal diante do chefe: o 'artista mesmo' é reconhecido por sua prática cotidiana” (1976: 39).

Como se percebe, a prática - o fazer - é o piso sobre o qual se assenta a legitimidade do saber, da prévia ideação. Contudo, apesar de se encontrarem nesse aspecto, para os pescadores artesanais, o caráter de subalternidade imposto pelo assalariamento na usina negaria o atributo de artista em seu mundo do trabalho, por ferir de morte o princípio da condição liberta de sua atividade, do uso do seu corpo, do pôr teleológico pesqueiro vivificado na busca da liberdade e de uma maior autonomia como valor de vida presente em sua arte. 
Duarte (1999: 95) descreveu que, para os pescadores de Jurujuba, RJ, trabalhar como assalariados em barcos industriais (as traineiras) retira o atributo de arte de sua ação produtiva, tendo em vista que assalariar-se apresenta-se "como lugar da subversão do código da arte", seu empobrecimento cognitivo e material.

De maneira geral, para os marítimos de Suape, há dois sujeitos que são tidos como exemplos da arte de pescar, no saber e fazer, embora eles sejam vistos - muitas vezes - como um só: o mestre e o bom pescador. Aquele é o protótipo da arte de pescar, seu arquétipo mais perfeito, e este o que já possui todo o domínio e pode transformar-se em breve num mestre, mas que precisa ser colocado à prova para merecer a honraria da mestrança. Tal prova surge em decorrência das próprias circunstâncias da pesca e da vida. Contudo, o talento do bom pescador, para enfrentá-la, já é reconhecido pelo mestre, mesmo que este não o diga. Não há um cerimonial, mas o desafio do imprevisto, segundo relato do pescador:

“- Quando é que o senhor virou mestre?

- Quando eu comecei a pesca com meus tios, eles me ensinavam a marcação. Marcações das terras, dois oiteiros. Eu aprendi também. Aprendi com os mestres, que eu pesquei mais eles.

- Quando é que eles souberem que o senhor poderia ser mestre?

- Quando um deles tava doente, eu fui tentar. Eles não disseram nada, não; deixaram. Eu fui no lugar de um deles. Eles tavam comigo todo dia, e isso se aprende, porque todo dia fazendo aquilo, aprende" [entrevista com seu Gidinha, mestre, 70 anos, Suape, PE].

O silêncio dos mestres significou certeza. Seu Gidinha já tinha sido ungido o suficiente nos caminhos dos mares, recebendo o reconhecimento por parte de seus tios, que eram mestres, de que ele era também portador da arte de pescar. Como disse o pescador seu Gidinha, "eles não disseram nada, não; deixaram" porque já era o momento de enfrentar o desafio de conduzir o barco e os homens no mundo aquático. Havia chegado, então, o tempo da mestrança afirmado pelo silêncio discursivo de seus mestres.

Em boa parte dos casos, é o pai quem prepara seu filho para ser mestre, quando esse mostra interesse e qualidade. A pesca é uma atividade familiar e de parceria, porém isso não confere ao filho a herança obrigatória da arte de pescar. $\mathrm{O}$ mestre é um educador, que avalia e reconhece o talento dos proeiros, nas formas de gestão do mar, e não deve desrespeitar esse preceito. A questão é evidenciada nas seguintes passagens:

"Se o camarada se dedicar, ele, o mestre, tem que repassar. Isso é importante. É uma profissão" [Conrado, mestre, 39 anos, Suape, PE]. 
"O meu filho começou comigo, negócio de puxando rede e tudo mais. Depois aprendeu a mergulhar. Acabou-se. O homem ficou feito" [seu Milton, mestre, 67 anos, Suape, PE].

Há um código ético balizado pelo reconhecimento do talento e dedicação dos que se tornarão mestres. Há um compromisso corporativo, de um ofício, de uma cultura do trabalho, do qual o mestre não pode se abster, porque ele "tem que repassar" a arte de ser pescador. Basta, então, para o pescador mestre Conrado, "o camarada se dedicar". Sendo assim, o saber-fazer pesqueiro não é propriedade privada, mas um bem comum que deve ser ensinado e difundido aos mais jovens, cujo conhecimento deve ser total em relação ao mundo pesqueiro. Assim,

"Essa totalidade do conhecer importa, porém, em outra questão. Como ela corresponde ao domínio de uma prática abrangente de vida, é a própria vida que a instaura progressivamente. Assim, o pescador feito é o resultado de um fazer paulatino que vai ao mesmo tempo fazendo quem faz. A 'senioridade' do mestre é também uma senioridade física e mental. O velho pescador (no sentido de um velho 'pequeno produtor') é o coroamento desse fazer pelo conhecer mais amplo” (Duarte 1999: 95, grifos no original).

Para o pescador, o valor de sua arte, antes de tudo, está em conferir maior perfeição ao seu trabalho, mais do que propriamente em gerar um objeto único. Esse valor colocado na perfeição também é uma herança das corporações de ofício, que se desdobraram em outras formas de artesanato, de artes populares, no Brasil.

“[...] para as camadas populares o conceito de artista está relacionado à ideia de competência, de domínio da arte. Da mesma forma, os juízos de valor sobre a obra se orientam, em primeiro lugar, por esses critérios de perfeição [...] A partir desse referencial, a singularidade da condição artística que se procura afirmar pela intenção da originalidade, a figura do criador solitário, carece de sentido, pois para o artista popular, o fundamental não é ser diferente, único, mas sim atingir a perfeição, ser capaz de expressar com as mãos aquilo que sua inteligência concebe" (Porto Alegre 1994: 106-107, grifos no original).

Sem dúvida, a noção de perfeição acaba sendo recorrente para definir a representação de beleza da mesma forma que arte, sendo partes de um todo da mestria:

"Conseguir pescar com qualidade, com perfeição e... é aí que tá o belo. O artista com seu talento, com a perfeição mesmo, é aí onde mora a beleza 
na pesca da gente. Acredito que é isso. Acho que talento e perfeição são a mesma coisa, é uma coisa somente, vivem ajuntados, pra mim, porque é arte, e se é arte, coisa de artista, então é também perfeição e é em tudo bonito, né?" [Jorge, proeiro, 23 anos, Suape, PE].

"O trabalho do mestre é a beleza maior da pesca, porque ele é perfeito, o cara sabe fazer de tudo" [seu Ulisses, proeiro, 66 anos, Suape, PE].

“Beleza é o cabra, que é pescador, fazer tudo na base da perfeição no barco" [Marco, mestre, 32 anos, Suape, PE].

Se a pesca é a perfeição do método e a perfeição é sinônimo de arte, o trabalho do pescador, no entender do jovem proeiro Jorge, "é em tudo bonito", porque é na perfeição que "mora a beleza na pesca da gente". Por isso, a objetivação da estética marítima encontra-se em "fazer tudo na base da perfeição no barco" [Marco], tendo por finalidade realizar boas pescarias. Diante disso, pode-se concluir "que o trabalho do mestre é a beleza maior da pesca, porque ele é perfeito" [seu Ulisses], esse é o talento maior do mundo aquático.

Assim, o valor moral da perfeição contida na arte do trabalho, do seu fazer, é componente de forte peso na esfera do ato produtivo da pesca artesanal suapense. Todavia, tal categorização não é algo que se restrinja ao mundo dos pescadores, visto que inúmeros artesãos (ou artistas populares) a levam em sua arte, na qualidade de um critério valioso. E isso desemboca no processo da mestria, isto é, "os diferentes valores convergem para uma síntese de relação com o trabalho e a obra produzida, que se expressa na reputação do mestre" (Porto Alegre 1994: 110 , grifo no original).

Todavia, como em grande parte dos casos, essa perfeição, essa arte torna-se herança familiar e o pai mestre será o "pedagogo" do saber-fazer pesqueiro de seu filho. É uma educação profissional tecida durante vários anos junto ao pai, de modo diário, que revela manejos náuticos e pesqueiros no ato de ouvir, ver, pesquisar e aprender fazendo. Ao fechar-se esse círculo de aprendizagem, "acabou-se", para seu Milton, aí "o homem ficou feito", seu filho também se transformou em um mestre de pescaria.

Além de todo o domínio da arte de pescar, um item assume valor preponderante para que um pescador torne-se mestre: saber o sistema de marcação. A marcação é uma forma de mapeamento do mar, seus caminhos e rotas mais seguras para se atingir os pesqueiros. Sem a marcação, o mar assumiria ares de impessoalidade, território sem nexo, jornada sem direção.

A marcação é elemento universal da pesca artesanal, existindo em inúmeras regiões do globo, seja no Canadá (Acheson 1981), seja em países escandinavos (Andersen 1980), seja no Brasil nos mais diversos estados (Cascudo 1957; Maldonado 1994; Ramalho 2017). 
As marcas, ou pesqueiros, são espaços produtivos no mar, os seus locais mais piscosos. ${ }^{6}$ Desta feita, as marcas são formas de apropriação social do território marítimo e de uso das potencialidades daquelas águas, em suas formas de gestão tradicional. A marcação é feita de maneira triangular, utilizando como referências pontos da terra e/ou do mar (movimento de correntes, pontas de arrecife, etc.). O continente é uma referência importante, já que os pescadores não ultrapassam, na maior parte dos casos, a plataforma costeira (ou parede, que se situa aproximadamente a 21 milhas náuticas), pelo fato de que isso não lhes permitiria ver a terra com qualidade, além do que a efetivação de tal deslocamento prejudicaria a pescaria e envolveria grandes riscos de morte para a tripulação, dada a tecnologia artesanal dos barcos e dos tipos de armadilhas de pesca utilizadas. ${ }^{7}$

Em relação ao sistema de marcação, dizem:

"A gente marca por terra, como se fosse um triângulo. Você marca aqui e aqui e o barco no meio. Vamos supor: você quer ir pra uma pedra. Você olha assim um coqueiro lá na terra e mais uns cinco km tem qualquer outra coisa. Aí esse coqueiro tem que estar alinhado com a outra marcação que está a cinco km dele. Chegar assim no meio é a marca que você vai correr. Chegou no alinhamento, você já tá na pedra" [Marco, mestre, 32 anos, Suape, PE].

Sobre isso, escreveu Maldonado:

"Um ponto fundamental à análise da marcação tanto dos bancos de peixe como dos roteiros das embarcações é a utilização dos 'marcos da terra' que é outro traço praticamente universal à pesca, muito significativo da forma como nela se realiza a unidade entre terra e mar. São sistemas de orientação dos pescadores, feitos dos sinais inscritos na natureza com a paisagem da terra, com os seus "marcos'” (Maldonado 1994: 108).

Esses pesqueiros e as rotas no mar são trunfos importantes para que a pesca exista e não seja atividade sinônimo de acaso. O conhecimento e a edificação desses mapas, que dependem da capacidade de descobri-los e memorizá-los, são bases essenciais do ápice da arte de ser pescador, o tornar-se mestre. Por

6 Os pesqueiros são, também, chamados de marcas, lanços, pedras ou pontos. São locais de abrigo e de alimentação de inúmeros tipos de pescado.

7 Uma milha marítima equivale a 1852 metros; então, para ir ao fim da plataforma costeira, navega-se cerca de 40 quilômetros. A parede é a última grande pedra (ou arrecife), onde se situa o fim da plataforma costeira. Após as paredes, a profundidade do oceano intensifica-se pela existência de um declive acentuado. Assim, além de o fundo tornar-se inacessível ou difícil para se utilizar a rucega (âncora) e de as redes não conseguirem mais condições de serem fixadas com precisão, o campo visual do pescador fica limitado, devido à ausência de referências em terra. 
isso, a marcação possui o atributo de levar a pessoa à mestrança, como fica claro no trecho abaixo:

"Quando começa a marcar [possui a mestria]. Se o cara quiser aprender a marcar, ele marca. Tem pescador que sobe no barco e dorme, e acorda só pra puxar a rede. Agora tem outro que fica ligado. Às vezes, a gente não sabe nem se ele sabe marcar, mas quando a gente tá chegando a cinco ou dez minutos do covo ele já tá com a luva na mão, ele já sabe. Esse pescador aí já tá ligado em alguma coisa. Esse já sabe marcar. Mas tem aquele pescador que o mestre tem que chegar no covo pra ele saber" [Genildo, mestre, 35 anos, Suape, PE].

A memória de mapas marinhos está incrustada no sistema de marcação, que marca a passagem para a mestrança. O pescador "marca” o mar e suas áreas mais piscosas, é esse o sinal da chegada à condição de mestre, da riqueza em se entender o ambiente marinho. Assim, a mestrança congrega o refinamento de conhecimentos náuticos, meteorológicos, hábitos de diversas espécies de pescado, marés, ventos, ciclos lunares, coordenação da tripulação e memorização das rotas e dos pesqueiros. Tudo isso se articula, formando um campo cognitivo complexo e rico, já que a ausência de combinação de um desses componentes limitaria a ação no mar, não permitindo o desenvolvimento do trabalho.

Tais mapas explicitam formas de apropriação social do mar, em suas mais diferentes maneiras de uso. A partir do descobrimento das rotas e dos pontos mais piscosos, o pescador mestre mapeia o espaço aquático de acordo com as características de cada pesqueiro, a saber, os que são mais (ou menos) propícios para o uso de determinados tipos de armadilhas (redes, linha e/ou covos), em decorrência da especificidade de cada pescado e de seus melhores modos de manejo.

Pela mestrança marítima passam formas de ordenamento e de manejo do mar fundadas em direitos costumeiros, em regras tradicionais de uso, que existem há décadas e até mesmo séculos, em boa parte das situações no Brasil, as quais fazem parte da cultura de aprendizagem, educativa, do ofício pesqueiro. Essas formas são transmitidas através de gerações sucessivas de mestres e podem ser traduzidas no direito à vez nos lanços comunais, com base em regras comuns e segredadas (Cordell 2001 ; Maldonado 2000; Ramalho 2006).

\section{O CORPO DO PESCADOR}

A questão da educação corporal voltada à pesca começa a ser desenvolvida logo cedo dentro da própria família em sua socialização, fundando-se no trabalho. Inicialmente, tarefas menores são repassadas aos filhos, que ainda não possuem estrutura física para suportar tempos maiores nas águas e nem detêm força suficiente para puxar e retirar redes do mar. 
Retirar a rede do mar ou o covo exige esforços físicos maiores, já que, além de a rede aumentar consideravelmente de peso quando está molhada, essas armadilhas trazem pescados, no êxito do trabalho, exigindo, assim, maior uso da força muscular dos proeiros, comum àquelas pessoas de maior estrutura corporal.

Os primeiros passos, no mundo embarcado, são dados na companhia do pai mestre (ou outros parentes que ocupam esse papel) em pescarias próximas à costa, antes da arrebentação, ou, quando muito, em poucas horas em mar alto, realizando trabalhos não pesados (pesca de linha e despesca) e sempre auxiliados de perto pela figura paterna. Quando vão para o mar de fora, os mais jovens ficam no meio do barco, porque na ponta fica o melhor proeiro - o bom pescador - e na popa vai o mestre, cabendo ao recém-marítimo observar e fazer o que eles pedem, ou apenas o que se observa e repete, enquanto elos do sistema de aprendizagem típicos de uma cultura de ofício. O barco também tem seus territórios do saber-fazer e seus momentos de conquista. Por exemplo, o antigo banco do mestre (ou banco de governo) existente na jangada transformou-se, com os botes, numa pequena cabine de comando (ou cabine do mestre), onde se situa o leme e o motor, estando na popa sob o governo do mestre. Tudo isso constrói e socializa o jovem dentro de um saber sensível direcionado ao trabalho pesqueiro, fato que prepara o sentir humano para desafios mais agudos.

Esse contato inicial com as linguagens do mar e suas regularidades possibilita, logo cedo, a construção de entendimentos humanos naturais acerca da natureza marinha e da própria fruição das forças essenciais do homem para melhor lidar com as águas, ora apresentados na capacidade de compreender os tipos de ventos e os movimentos das marés, ora explicitados na habilidade para descobrir pesqueiros e ouvir e sentir as mudanças náuticas e meteorológicas. Além disso, permite ao futuro pescador conhecer a si e ao mundo, com vistas a desenvolver melhor sua fruição sensível, expressar disposições sociais e culturais, onde o corpo e seus sentidos são fundamentais.

"O mundo é compreensível, dotado imediatamente de sentido, porque o corpo, tendo a capacidade de estar presente no exterior de si mesmo, no mundo, graças a seus sentidos e a seu cérebro, e de ser impressionado e duravelmente modificado por ele, ficou longamente (desde a origem) exposto a suas regularidades. Tendo adquirido por esse motivo um sistema de disposições ajustado a tais regularidades, o corpo se acha inclinado a apto a antecipá-las praticamente em condutas que mobilizam um conhecimento pelo corpo capaz de garantir uma compreensão prática do mundo bastante diferente do ato intencional de decifração consciente que em geral transparece a ideia de compreensão" (Bourdieu 2007: 165-166, grifo no original). 
O corpo é o momento inicial de aprendizagem e do fazer-se humano, fato valorizado por uma diversidade de autores e, desse modo, por matizes plurais do pensamento acerca do social. No entendimento de Hegel, "a consciência sensível é, no homem, a primeira, a que precede todas as outras" (1996: 133); para Marx, "a sensibilidade tem de ser a base de toda ciência" (2004: 112, grifo no original); de acordo com Mauss, "o corpo é o primeiro e o mais natural instrumento do homem" (2003: 407); na compreensão de Haroche, é necessário "dar outro lugar à corporeidade, ao movimento, à mobilidade, à mudança nos processos de pensamento" (2008: 226); ou, na concepção de Wacquant, "a sociologia deve se esforçar para capturar e restituir essa dimensão carnal" (2002: 1 1); e, segundo Foucault, "é pelo estudo dos mecanismos que penetram nos corpos, nos gestos, nos comportamentos, que é preciso construir a arqueologia das ciências humanas" (1979: 151). De fato, como destacou Weber, torna-se essencial "dar conta do lugar do corpo na experiência pessoal" (2009: 267), apoiando-se numa etnografia das percepções sensoriais.

O mundo sensitivo enseja a descoberta de tipos de educação, conhecimentos e posições sociais diferenciadas. Por isso, "o corpo do burguês não é o corpo do artesão ou do operário" (Le Goff e Truong 2006: 30), tampouco o do pescador. Dessa maneira, diferentes formas de sociabilidade produzem educações corporais e sensitivas distintas no transcurso do tempo e nas mediações sociais particulares, seja em seus aspectos materiais, seja nos ingredientes simbólicos. Assim, "não só pensar, portanto, mas com todos os sentidos o homem é afirmado no mundo objetivo" (Marx 2004: 1 10, grifo no original), efetivando-se enquanto ser social especialmente pelo trabalho.

A existência sensível, portanto, vincula-se, em grande medida, à organização material da existência dos indivíduos em seu processo de desenvolvimento e criação (no metabolismo humano com a natureza), que reproduz e desenvolve também os sentidos humanos, como pressupostos dessa organização. Então, a produção objetiva da vida humana tornou-se

“[...] tanto uma pré-condição de sua atividade, como é sua própria pele, como são seus órgãos sensoriais, pois toda a pele, e todos os órgãos dos sentidos são, também, desenvolvidos, reproduzidos, etc., no processo da vida, quanto pressupostos deste processo de reprodução" (Marx 1991: 78).

O corpo do pescador é lapidado e construído no fazer da cultura marítima, na busca do dever-ser, no fazer-se artista da pesca artesanal. No mundo da pescaria, o verbo faz-se carne, a abstração concretiza-se e, então, o mais jovem tenta tornar-se pescador feito, um artista do mar, fazendo-se no ato de fazer.

"Eu comecei na pesca de linha. Coisa maneira. Depois vai aumentando, né? A gente vai ficando mais forte, né? Aprende a usar o corpo e saber o que 
vai fazer. O corpo do pescador... o cabra fica já pronto mesmo pra pescar, pra vida dele. Sabe usar o corpo em tudo" [seu Neneu, mestre, 67 anos, Suape, PE].

$\mathrm{Na}$ fala de seu Neneu, o momento em que o pescador "aprende a usar o corpo e saber o que vai fazer" clarifica que o corpo não se desvincula da história, das determinações de existir dos pescadores, onde não há uma mera adaptação biológica e sim a constituição de um complexo processo sociocultural transmitido aos sentidos, como condição para o desenvolvimento de uma cultura humana específica.

$\mathrm{Na}$ pesca, os momentos inaugurais de sua pedagogia apoiam-se na feitura de pequenos esforços físicos e cognitivos intrínsecos à formação dos pescadores, fato que se repete a cada geração na constituição do saber sensível pesqueiro orientado de perto pelo mestre, na socialização produtiva no mar. Desta feita, os corpos e o sentir dos sentidos dos pescadores são lapidados pelo toque das vagas, do sol, da brisa, do som que brota do mar, pela visão dos cardumes, pela pesca e despesca, pelo manter-se em pé no barco, pelo enfrentar os balanços do mar e, principalmente, pelo convívio social cotidiano. "Assim é que as crianças vão-se iniciando nas atividades da pesca, fazendo pequenos serviços como 'pontas-de-cabo', e logo que tenham 'físico' para remar, já podem passar a companheiros-de-remo" (Lima 1997: 168).

A pesca é tecida também pelo lúdico, posto que, para o pescador seu Milton, "a pesca começou como divertimento, mergulhando e começando a saber das coisas”. O fascínio das águas (dos seus seres e dos desafios) apresenta-se como universo estimulante a ser conquistado pelos mais jovens, que em suas brincadeiras estabelecem culturas corporais e se preparam intelectualmente, ao prepararem seus sentidos para conquistarem a arte de ser pescador.

Quem decide o momento de ir ao mar de fora não é somente o jovem, mas o mestre, que é seu pai, tio ou irmão mais velho; é um momento repleto de cuidados, visto que perder um membro da tripulação no mar é forte demérito para um bom mestre, além de envolver, na maioria das situações, sentimentos filiais. É claro que as necessidades materiais, de ter mais gente da família pescando para prover a casa de alimentos e renda monetária, contam e muito, porém é o mestre quem avalia o preparo para acumular e/ou passar para certas funções, é ele quem sabe qual é o tempo certo para que se possa embarcar ao encontro do mar alto.

Orientar e saber o momento certo do corpo e do amadurecimento cognitivo necessário para a faina no mar - projetada no jeito de trabalhar e desenvolver a pescaria em técnicas manuais, visuais, rítmicas para pôr e retirar a rede -, esse é um dos papéis do mestre. Corpo e mente devem ser um só no que for possível na pesca. O deslocamento para atividades mais sofisticadas "depende fundamentalmente da avaliação do mestre" (Lima 1997: 169), da sua certeza 
de que determinado indivíduo pode realizar, de agora em diante, tal tarefa e não mais somente aquela. São os percursos iniciais para se alcançar o todo, a arte da pesca. Assim, "o mestre testa os proeiros sem eles saberem: 'Olha, faz isso!' " [seu Gidinha, mestre], para observar aptidões presentes ou não.

Nesse sentido, há o que pode ser classificado de uma progressão na pesca artesanal oriunda do talento, onde a ascensão nas atividades é definida sem imposições individuais. Evidentemente que cabe ao mestre avaliar cada um, porém os critérios são conhecidos coletivamente e ganham o aval também da tripulação, haja vista que a qualidade do pescador deve ser demonstrada objetivamente no seu criar sensível, diariamente. Assim, a passagem a outra função, no barco, torna-se natural. Esse circuito não conduz, mecanicamente, o pescador ao posto de mestre, no decorrer de sua vida. Ele pode ser considerado um artista, mas sem atingir jamais a sua graduação máxima, a mestria, por não ter adquirido os talentos sensitivos e abstratos em plenitude.

No caso do talento marítimo, a agudização da habilidade encarna-se nas funções assumidas no barco. Como pude observar nos barcos em alto-mar, os mais jovens exercem atividades de menor complexidade e ficam, normalmente, no centro da embarcação. Todavia, isso não é o mesmo que afirmar que eles não são importantes, visto que, ao cumprir atividades essenciais como, por exemplo, desmalhar os peixes e, às vezes, colocá-los no gelo, o pescador mais novo deixa os outros proeiros livres para assumirem tarefas mais exigentes. Quando não há jovens, o trabalhador menos hábil também não deixa de assumir papel valioso, só que com exigências bem maiores que as colocadas aos mais novos. Decorrente disso, o melhor proeiro, por deter sofisticada capacidade de externar seu saber e fazer, localiza-se na ponta do barco, lançando e retirando as redes, pegando com o bicheiro (uma vara de mais de dois metros com um gancho na ponta) as boias dos covos e redes, etc., quando o barco - muitas vezes - está em pleno movimento, sendo auxiliado pelo proeiro do centro e também pelo que fica mais atrás, principalmente. Este último é mais capacitado que o do centro, por ser responsável por puxar a rede e alinhá-la no momento de sua retirada do mar. Ele é chamado de chumbeiro por pegar essa parte da rede na hora de puxá-la do oceano.

No que concerne ao proeiro da ponta, esta é a derradeira função antes de se alcançar a mestrança. A ascensão só ocorrerá se o proeiro conseguir realizar a marcação, como indiquei. A ação produtiva executada por tal trabalhador é rica em destreza. Sua leitura e manejo corporal ágeis o revestem de papel essencial no mundo produtivo, ganhando reconhecimento dos demais proeiros e admiração advinda do próprio mestre. Em várias oportunidades, o mestre lê os gestos do proeiro da ponta, para depois poder agir e vice-versa; a comunicação é plenamente corporal, devido ao som do motor e/ou para não afastar peixes mais sensíveis e que poderiam fugir diante de sonoridades estranhas. 
De fato, o da ponta "sabe mais" que os outros proeiros, porque "ele é quem faz o primeiro movimento" e decisivo ato com talento agudo, dado que está "de costas pro mar e tem que ter equilíbrio ao mesmo instante" [Edson, mestre, 41 anos, Suape, PE], "olhando pro mestre" [Gildo proeiro, 45 anos, Suape, $\mathrm{PE}]$ para saber se tudo se encontra em bom termo, para que a equipe possa de modo integrado e no ritmo correto efetivar o processo de cooperação essencial à pesca. A feitura hábil e sofisticada do proeiro da ponta o deixa na condição de "quase mestre", precisando apenas realizar o desfecho decisivo e final para o controle definitivo da arte de ser pescador: "falta somente marcar" [Genildo, mestre, 35 anos, Suape, PE]. De maneira geral, toda a atividade feita a bordo é respeitada, porque ela é central para o sucesso da pescaria. Sem dúvida, "todos, do barco, são importantes" [Genildo, mestre, 35 anos, Suape, PE] e necessários para que a sociedade do trabalho aconteça. Não há, entre os pescadores, desrespeitos ou funções consideradas sem valor ou de valor menor. Tudo tem seu grau de significância para o funcionamento do barco, e, por isso, os ganhos são repartidos igualmente através do quinhão (como salientado anteriormente), cabendo apenas ao mestre sua parte e a que é destinada à rede, especialmente por ela ficar sob sua responsabilidade no que diz respeito aos reparos necessários da malha.

O corpo também é o espaço do diálogo, dos sinais e signos produtivos utilizados pela tripulação para se entender no mar, formando uma semiótica da pescaria. No barco, "ninguém fala" por palavras, pois "a gente se comunica com os gestos" [Gildo] típicos do saber-fazer pesqueiro. Essa é a linguagem pesqueira, a do uso corporal, onde "os sentidos humanos deverão se transformar em elaboradores de teorias" (Lukács 1978: 17) para que os marítimos atinjam a condição de artífices do oceano, enquanto resultado de sofisticadas elaborações cognitivas expressadas e que expressam o criar sensível, o saber-fazer pesqueiro, ao identificarem, pelos sentidos, os tipos de ventos, cheiros de pescados, sons e colorações das águas mais piscosas. Dessa maneira,

"Ele [o corpo] não representa o que expressa, não memoriza o passado, ele age o passado, assim anulado como tal, ele o revive. O que é aprendido pelo corpo não é algo que se tem, como um saber que se pode segurar diante de si, mas algo que se é. Isso pode ser visto particularmente nas sociedades sem escrita em que o saber herdado não pode sobreviver senão no estado incorporado" (Bourdieu 2009: 120, grifo no original).

No trabalho artesanal marítimo, a prática da mestrança é o próprio dever-ser individual da arte de ser pescador. Sua técnica expressa-se não no uso da força - tendo em vista que os mestres, em boa parte dos casos, são os pescadores com mais idade -, mas no refinar humanizador dos sentidos corporais que um homem deseja atingir no mar, no autocontrole psicológico e físico, na 
realização da sua autoatividade embarcada. Saber usar os sentidos é fundamental para atingir a mestria, o último e mais completo estágio da arte de ser pescador.

O mestre é portador das leituras sensitivas e mentais mais elaboradas, cuja tradução apresenta-se no ato talentoso de encontrar pesqueiros, de marcá-los e saber guiar-se no mar, posto que "o mais difícil no mar é marcar" [seu Neneu, mestre].

Marcar as áreas mais piscosas do mar - de acordo com mapas - é trazer a natureza marinha à humanização edificada pela história cotidiana desses homens das águas, por meio da capacidade dos seus sentidos, que a consciência trabalhou artesanalmente ao longo do tempo, nos seus caminhos no mar; "assim os seus caminhos, texturas e contornos, variáveis através das estações do ano, são incorporados em suas próprias capacidades corporificadas de movimento, consciência e resposta" (Ingold 2015: 90). Por isso, sons na água, sinais de cor, as formações de nuvens, os tipos de marés são decifrados enquanto elos indissociáveis da relação humana com a natureza, ao introduzi-los como componentes relevantes do modo de vida do pescador e da sua reprodução ao longo dos anos. Todos os embarcados detêm atributos de refinadas leituras sensitivas náuticas e pesqueiras, porém ninguém igual ao mestre, fenômeno típico da sua cultura de ofício. Desmistificar o mundo aquático e as variáveis que o formam - articulando-as profundamente - é fator determinante da mestrança.

A fala do pescador Gildo (proeiro, 45 anos) indica que marcar é saber usar bem o corpo, sua fruição. O mestre, como nenhum outro ser humano, "sabe usar melhor a visão e o ouvido" para compreender o que o mar mostra e diz, objetivando encontrar os pesqueiros "quando o peixe tá fazendo batida e tem brilho diferente" [seu Milton, mestre, 67 anos, Suape, PE] no mar; depois é marcar na consciência o que foi decodificado sobre a vida marinha, para que se possa "saber mais os locais de pescar" [Gildo], e "aí ele [o pesqueiro] fica pra ele [o mestre que o conhece]" [seu Milton], envolvendo o ponto de pesca descoberto em segredo. O corpo humanizado desse pescador resulta de "muita alembração" [seu Gidinha, mestre, 70 anos, Suape, PE] acerca dos lugares marinhos, de uma aguda consciência para estabelecer uma comunhão insofismável com as águas, através de seu saber-fazer, da memória e dos comandos precisos no mar. Assim, "para conseguir ser um artista, é necessário dominar, controlar e transformar a experiência em memória, a memória em expressão, a matéria em forma" (Fischer 1976: 14), pelo amadurecimento das faculdades humanas e de seu autocontrole na condução do mundo embarcado, como base de sua cultura de ofício.

Seu apuro - edificado no tempo da vivência - traduz-se em um eterno dever-ser para que a pesca se atualize e se realize exitosamente, como trabalho autônomo. Por isso, “o corpo está ligado a um lugar por uma relação direta, de 
um contato que não é senão uma maneira entre outras de entrar em relação com o mundo" (Bourdieu 2007: 165).

\section{CONCLUSÃO}

O trabalho da pesca artesanal caracteriza-se por ser uma atividade que exige um rico saber-fazer, um processo longo de socialização produtiva, de sofisticada habilidade aprendida, desenvolvida e reproduzida no corpo; o processo de mestria, de fazer-se mestre, artista do mar, é seu ponto de chegada e de partida.

O sentimento do trabalho vivido como arte encontra na cultura de ofício pesqueira, no sentimento de corporação, sua base de produção e de reprodução material e simbólica ao longo dos anos. Assim, a formação dos homens que pescam, através da sua educação profissional e das práticas de apropriação social sofisticadas em relação ao ambiente aquático, atua no intuito de privilegiar o valor central da cultura profissional de um ofício - sua atividade como arte, práticas de manejo pesqueiro e usos dos territórios piscosos -, encontrando na figura do mestre o símbolo maior desse mundo, do saber-fazer, do seu sistema de aprendizagem, enquanto portador de toda uma tradição cultural contida numa forma específica de trabalho e de seu repasse, a da arte de fazer-se pescador artesanal.

Aqui não há uma separação entre trabalho e vida e nem entre trabalho e família. A arte pesqueira, os mestres e o modo de vida dos pescadores artesanais se confundem, por serem elos inelimináveis do processo de produção e reprodução social da atividade pesqueira e de suas maneiras de uso do ambiente aquático. 


\section{BIBLIOGRAFIA}

ACHESON, James, 1981, “Anthropology of fishing”. Annual Review of Anthropology, 10: 275$-316$.

ALVIM, Maria Rosilene Barbosa, 1972, A Arte do Ouro: Um Estudo sobre os Ourives de Juazeiro do Norte, CE. Rio de Janeiro, Museu Nacional/UFRJ, dissertação de mestrado em Antropologia Social.

ANDERSEN, Raoul, 1980, "Hunt and conceal: information management in Newfoundland deep-sea trawler fishing”, em S. K. Tefft (org.), Secrecy: A Cross-Cultural Perspective. Nova Iorque e Londres, Human Sciences Press, 205-228.

BARbOSA, Alexandre de Freitas, 2008, A Formação do Mercado de Trabalho no Brasil. São Paulo, Alameda.

BOURdieu, Pierre, 2007, Meditações Pascalianas. Rio de Janeiro, Bertrand Brasil.

Bourdieu, Pierre, 2009, O Senso Prático. Petropólis, Vozes.

CASCUDO, Luís da Câmara, 1957, Jangadeiros. Rio de Janeiro, SAI.

COllet, Serge, 1993, Uomini e Pesce: La Caccia al Pesce Spada tra Scilla e Cariddi. Milão, Giuseppe Maimone Editore.

CORDELL, John, 2001, "Marginalidade social e apropriação territorial marítima na Bahia", em A.C. Diegues e A.C. Moreira (orgs.), Espaços e Recursos Naturais de Uso Comum. São Paulo, NUPAUB/USP, 139-160.

COSTA, Francisco Augusto Pereira da, 1954, Anais Pernambucanos: 1740-1794, vol. VI. Recife, Arquivo Público Estadual.

CUNHA, Luiz Antônio, 2000, O Ensino de Ofícios Artesanais e Manufatureiros no Brasil Escravocrata. São Paulo, Editora da Unesp; Brasília, DF, Flacso.

DIEGUES, Antonio Carlos, 1983, Pescadores, Camponeses e Trabalhadores do Mar. São Paulo, Ática.

DIEGUES, Antonio Carlos, 2000. "Navegando pelas montanhas: pesca de marcação e mestrança em Galinhos, Rio Grande do Norte, Brasil”, em A.C. Diegues (org.), Imagem das Águas. São Paulo, Hucitec, 65-84.

DUARTE, Luiz, 1999, As Redes do Suor. Niterói, EdUFF.

FISCHER, Ernst, 1976, A Necessidade da Arte. Rio de Janeiro, Jorge Zahar Editor.

FOUCAUlT, Michel, 1979, Microfísica do Poder. Rio de Janeiro, Graal.

FREYRE, Gilberto, 2003, Sobrados \& Mucambos. São Paulo, Editora Global.

GALVÁN TUDELA, Alberto, 1989, "Estrategias económicas en la pesca artesanal canaria”, Actas de las Jornadas de Economía y Sociología de las Comunidades Pesqueras, Madrid, Universidad de Santiago de Compostela/Ministerio de Agricultura, Pesca y Alimentación, 495-510.

HAROCHE, Claudine, 2008, A Condição Sensível. Rio de Janeiro, Contra Capa.

HEGEL, Georg W.F., 1996, Curso de Estética: O Belo na Arte. São Paulo, Martins Fontes.

HOBSBAWM, Eric J., 1987, Mundos do Trabalho. Rio de Janeiro, Paz e Terra.

INGOLD, Tim, 2015, Estar Vivo. Petropólis, Vozes.

JUNQUEIRA, Eduardo, 2003, "Introdução", em G. Malheiros e E. Junqueira, Embarcações

Brasileiras. Rio de Janeiro, Arte Ensaio Editora, 10- 11.

LANGHANS, Franz-Paul, 1948, A Casa dos Vinte e Quatro de Lisboa: Subsídios para a Sua História. Lisboa, Imprensa Nacional.

LE GOFF, Jacques, e Nicolas TRUONG, 2006, Uma História do Corpo na Idade Média. Rio de Janeiro, Civilização Brasileira. 
LIMA, Roberto Kant de, 1997, Pescadores de Itaipu. Niterói, EdUFF.

LOPES, José Sérgio Leite, 1976, O Vapor do Diabo: O Trabalho dos Operários do Açúcar. Rio de Janeiro, Paz e Terra.

LUKÁCS, Georg, 1978, "As bases ontológicas do pensamento e da atividade do Homem", Temas de Ciências Humanas, 4: 1-18.

MAC CORD, Marcelo, 2012, Artífices da Cidadania: Mutualismo, Educação e Trabalho no Recife Oitocentista. Campinas, Editora da Unicamp.

MALDONADO, Simone, 1994, Mestres e Mares. São Paulo, Annablume.

MALDONADO, Simone, 2000, "A caminho das pedras", em A.C. Diegues (org.), Imagem das Águas. São Paulo, Hucitec, 59-68.

MARQUeS, A.H. de Oliveira, 1985, História de Portugal, vol. I: Das Origens ao Renascimento. Lisboa, Palas Editores.

MARTINS, Mônica de Souza, 2008, Entre a Cruz e a Espada: As Corporações de Ofícios no Rio de Janeiro após a Chegada da Família Real, 1808-1824. Rio de Janeiro, Garamond.

MARTINS, João Furtado, 2017, "Os carpinteiros na Inquisição de Lisboa no século XVIII: trabalho, sociabilidades e cultura material”, Librosdelacorte.es (monográfico), 6: 256-281. MARX, Karl, 1991, Formações Econômicas Pré-Capitalistas. São Paulo, Paz e Terra.

MARX, Karl, 2004, Manuscritos Econômico-Filosóficos. São Paulo, Boitempo.

MAUSS, Marcel, 2003, Sociologia e Antropologia. São Paulo, Cosac Naify.

OSBORne, Harold, 1970, Estética e Teoria da Arte: Uma Introdução Histórica. São Paulo, Cultrix.

PeIXOTO, Maria Inês Hamann, 2003, Arte e Grande Público: A Distância a Ser Extinta. Campinas, Autores Associados.

PORTO AlEGRE, Sylvia, 1994, Mãos de Mestres: Itinerários da Arte e da Tradição. São Paulo, Maltese.

RAMAlHO, Cristiano Wellington Noberto, 2006, Ah, Esse Povo do Mar. São Paulo, Editora Polis; Campinas, Ceres/Unicamp.

RAMALHO, Cristiano Wellington Noberto, 2017, Embarcadiços do Encantamento: Trabalho

Sinônimo de Arte, Estética e Liberdade na Pesca Marítima. Campinas, Ceres-Unicamp; São Cristóvão, Edufs.

RUGIU, Antonio S., 1998, Nostalgia do Mestre Artesão. Campinas, Autores Associados.

SENNETT, Richard, 2009, O Artífice. Rio de Janeiro, Record.

SERrÃo, Joel, 1971, Dicionário de História de Portugal, vol. III. Porto, Iniciativas Editoriais.

SILVA, Luiz Geraldo, 2001, A Faina, a Festa e o Rito: Uma Etnografia Histórica sobre as Gentes do Mar (Séculos XVII ao XIX). Campinas, Papirus.

SILVA, Fernando Teixeira da, 2003, Operários sem Patróes. Campinas, Editora da Unicamp. WACQUANT, Loïc, 2002, Corpo e Alma. Rio de Janeiro, Relume Dumará.

WEBER, Florence, 2009, Trabalho Fora do Trabalho. Rio de Janeiro, Garamond.

WOLFF, Janet, 1981, A Produção Social da Arte. Rio de Janeiro, Jorge Zahar Editor. 